\title{
ANALISIS KEMAMPUAN BERPIKIR KRITIS MAHASISWA PENDIDIKAN FISIKA SEMESTER 3 TENTANG PEMANFAATAN TEKNOLOGI SOLAR CELL TERHADAP LINGKUNGAN
}

\author{
${ }^{1 *}$ Rosdiana Afifah Rahman, ${ }^{2}$ Sudarti \\ 1 Program Studi Pendidikan Fisika FKIP Universitas Jember \\ 2 Program Studi Pendidikan Fisika FKIP Universitas Jember
}

*Email : rosdianaafifah@gmail.com

\section{INFO ARTIKEL}

Diterima : 05 Desember 2020

Direvisi : -

Dipublikasikan : 31 Januari 2021

\begin{abstract}
This article aims to analyze students' understanding of the purpose of solar cell technology. Because the role of students is very important in developing one of the renewable energies that is solar cells. There are still many people who have not seen other benefits from the sun, as well as ways to use solar energy for other processes, such as the use of solar cells in households and so on. Most of humans have not seen other ways and benefits of solar energy. So that to socialize the use of solar cell technology, students need to understand how important solar energy is as a renewable energy and how to use it. The method used in this study used quantitative descriptive, with the sample of 2019 class of physics education students.
\end{abstract}

Keywords: Solar cell, Environment, Renewable.

\section{Pendahuluan}

Energi merupakan salah satu kebutuhan dasar makhluk hidup, sehingga tanpa adanya energy makhluk hidup tidak akan dapat untuk bertahan. Pemenuhan kebutuhan energi dapat dilakukan dengan mengkonversi sumber energy menjadi bentuk energy yang dapat menggerakkan berbagai peralatan teknologi untuk melakukan kegiatan keberlangsungan hidup bagi makhluk hidup. Teknologi konversi energy memanfaatkan dari jenis sumber energy yang tersedia di alam, dan juga teknologi ini direkayasa dari proses konversi energy alam.

Energy yang banyak digunakan saat ini yaitu energy listrik. Namun, seiring banyaknya pemakaian tersebut berdampak pada sumber energy listrik tersebut. Ketersediaan sumber energy listrik saat ini mulai menipis dan tidak mampu untuk memnuhi kebutuhan listrik di Indonesia. Salah satu sumber energy dari listrik yaitu sumber energy fosil. Sedangkan sumber energy fosil saat ini jumlahnya terbatas dan sumber energy ini sifatnya tidak dapat diperbarui. Sehingga terdapat pengembangan teknologi untuk mendapatkan sumber energy lain, yaitu energy terbarukan.

Salah satu energy yang terdapat di alam yaitu energy matahari. Bentuk lain dari energi matahari yaitu cahaya. Energy matahari dapat dipakai secara langsung maupun tidak langsung. Contoh pemakaiana secara langusng yaitu, dengan adanya cahaya dari matahari, makhluk hidup dapat melihat dan juga dapat melakukan kegiatan sehari-hari seperti memasak, menghangatkan rumah, dan lain sebagainya. Pemakaian secara tidak langsung dapat diketahui ketika menggerakkan pembangkit listrik tenaga air. (Nya Daniaty Malau, 2019).

Energi matahari merupakan salah satu dari beberapa macam energi terbarukan yang ada. Energy yang dipancarkan matahari untuk meyinari bumi dapat bermanfaat bagi penduduk bumi. Namun, pemanfaatan energy matahari belum dimaksimalkan dengan sepenuhnya oleh sebagian besar masyarakat. Energy matahari oleh sebagian masyarakat hanya dimanfaatkan untuk mengeringkan pakaian dan mengeringkan hasil panen. 
Penggunaan energy matahari memiliki banyak kelebihan yaitu, energy ini ramah lingkungan dan bebas polusi. Ketersediaan energy matahari juga banyak sehingga dapat dikatakan tidak terbatas. Tetapi terdapat kelemahan lain yaitu, energy ini tergantung dari cuaca lingkungan. Sehingga untukmengumpulkan energy tersebut dibutuhkan sistem penyimpanan energy.

Energi surya diperkirankan akan mencapai lebih 60\% dari total energy masa depan. Dikarenakan harga minyak yang terus naik dan cadangannya semakin menipis, juga akibat kenaikan polusi yang semakin meningkat, maka solusi alternatifnya yaitu meningkakan kesadaran tentang bahaya akibat dicari dan terus dikembangkan. Energy surya merupakan sumber energy yang sangat menjanjikan karena jumlahnya sangat besar dan sifatnya yang lebih terjaga. Total energy surya yang sampai di permukaan bumi adalah 2,6.1024 Joule setiap tahun. Besar energy surya yang tersedia saat ini ini $10^{4}$ kali besar kebutuhan energy dunia yang mencapai 2,6.1020 Joule/tahun (Yoyok Cahyono, 2018).

Pemahaman mahasiswa mengenai pemanfaatan teknologi solar cell sangat diperlukan. Karena mahasiswa merupakan agent of change yang nantinya berperan penting dalam proses pengembangan energy terbarukan, salah satunya solar cell. Selain itu, mahasiswa juga dapat berperan dalam mensosialisasikan tentang bagaimana pentingnya pemanfaatan teknologi solar cell beserta cara penggunaanya dalam memanfaatkannya. Karena seperti yang sudah dijelaskan diatas bahwa pemanfaatan teknologi solar cell belum dimanfaatkan seluruhnya.

\section{Metode Penelitian}

Penelitian ini fokus pada pemahaman mahasiswa dan pikiran kritis mengenai pemanfaatan teknologi solar cell pada lingkungan. Sehingga, metode yang digunakan pada penelitian ini yaitu metode deskriptif kuantitatif. Untuk mengumpulkan data penelitian dengan mengunakan kuesioner atau angket yang disebarkan pada mahasiswa pendidikan fisika angkatan 2019. Kuesioner tersebut mengguanakan google form dan disebarkan melalui group WhatsApp.

Responden yang dibutuhkan dalam metode ini yaitu minimal 40 responden. Hal ini untuk mengetahui persebaran tingkat pemahaman dan tingkat berpikir kritis mahasiswa pendidikan fisika angkatan 2019. Data dari penelitian ini diperoleh dengan melihat persebaran tersebut, sehingga peneliti mampu melihat persebaran dari tingkat pemahaman dan berpikir kritis mahasiswa pendidikan fisika angkatan 2019 tentang manfaat teknologi solar cell.

Kusioner dari penelitian ini berisi 8 pertanyaan. Adapun isi dari pertanyaan tersebut terdapat beberapa yg sesuai dengan bacaan yang sudah tertera. Kemudian terdapat pertanyaan dimana semua jawaban dari pertanyaan tersebut benar, namun terdapat point dari masing-masing jawaban tersebut. Hal ini untuk mengetahui dan menilai tingkat pemahaman dan berpikir kritis mahasiswa pendidikan fisika angkatan 2019.

\section{Hasil dan Pembahasan}

Berdasarkan hasil angket kuesioner yang telah disebar dan diisi oleh mahasiswa Pendidikan Fisika angkatan 2019, diperoleh hasil bahwa nilai median yang diperoleh ketika mengisi kuesioner yaitu 40, dengan ratarata nilai yaitu 52,26 dari total niali 120. Hal ini menandakan bahwa sebaian mahasiswa masih belum paham mengenai pemanfaatan teknologi solar cell. Hasil tersebut juga menunjukkan bahwa sebagian mahasiswa juga belum dapat berpikir kritis mengenai teknologi pemanfaatan solar cell. 


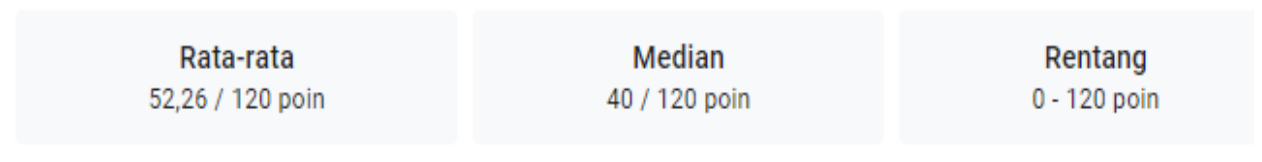

\section{Distribusi poin total}

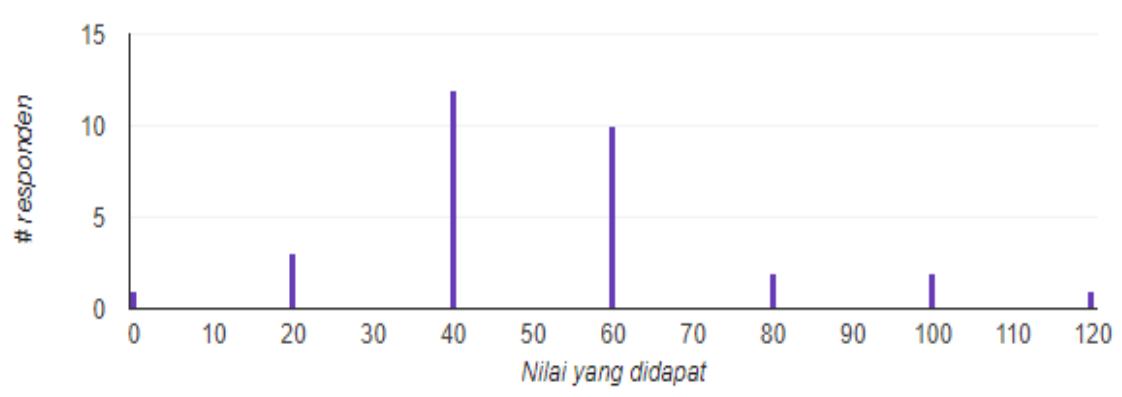

Soal nomor 1 mengenai pemanfaatan solar cell. Berdasarkan data hasil angket kuesioner menunjukkan bahwa sebagian besar atau sebesar 58,1\% responden menjawab benar mengenai pemahaman pemanfaatan solar cell. Hal ini menunjukkan bahwa responden sudah memiliki pemahaman mengenai teknologi pemanfaatan solar cell. Sehingga dapat dikatakan bahwa responden sudah dapat berpikir kritis mengenai pemanfaatan solar cell.

Berikutnya soal nomor 2 mengenai hubungan matahari dengan energi. Sebesar 90,3\% responden menjawab benar mengenai hubungan matahari dan energi. Berdasarkan data hasil angket kuesioner tersebut, dapat ditarik makna bahwa sebagian besar responden sudah memahami mengenai teknologi pemanfaatan solar cell. Sebagian besar responden juga dapat ikatan mampu untuk berpikir kritis mengenai hubungan matahari dengan energi. Hal ini karena jawaban yang terdapat dalam text tersirat, sehingga responden harus dapat menyimpulkan sendiri dan berpikir kritis mengenai jawaban dari soal tersebut.

Berdasarkan data hasil kuesioner soal nomor 3 mengenai urutan yang benar tentang cara kerja listrik tenaga surya yaitu, sebesar 51,6\% jawaban responden benar. Hal ini menunjukkan bahwa responden sudah paham mengenai cara kerja listrik tenaga surya. Sehingga dapat dikatakan bahwa respon sudah memahami tentang cara kerja listrik tenaga surya.

Berikutnya soal nomor 4 mengenai tingkat kehandalan dari PLTS. Terdapat dua jawaban benar pada soal ini, hal ini karena untuk menguji tingkat pemahaman dan pikiran kritis responden mengenai tingkat kehandalan dari suatu PLTS. Berdasarkan data hasil kuesioner yang terkumpulkan diperoleh sebesar 61,3\% untuk jawaban benar pertama, dan 67,7\% untuk jawaban benar kedua. Berdasarkan hasil tersebut dapat ditarik makan bahwa sebagian besar resonden sudah paham dan mampu berpikir kritis mengenai tingkat kehandalan dari suatu PLTS.

Pertanyaan nomor 5 mengenai bagian-bagian dari penyususn sel surya. Terdapat bacaan dalam pertanyaan ini, sehingga responden dapat mengambil atau mendapatkan jawaban dari pertenyaan tersebut melalui bacaan. Jawaban yang terdapat dalam bacaan tersebut tersirat, sehingga responden harus bisa berpikir kritis dan memahami bacaan tersebut agar menemukan jawaban. Berdasarkan data hasil angket kuesioner, sebesar 32,3\% reponden menjawab benar. Sehingga berdasarkan nilai tersebut dapat diketahui bahwa pada pertanyaan nomer 5 ini, reponden belum dapat berpikir kritis mengenai bagian-bagian dari penyusun solar cell.

Pertanyaan terakhhir yaitu pertanyaan nomor 6 mengenai fungsi dari salah satu penyusun sel surya. Terdapat bacaan dalam soal tersebut mengenai fungsi dari salah satu komponen sel surya dan diiharapkan responden mampu menangkap makna tersirat dalam bacaan tersebut untuk menjawab jawaban yang benar. Berdasarkan data yang diperoleh yaitu sebesar $22,6 \%$ responden menjawab benar. Sehingga berdasarkan data tersebut diketahui bahwa responden ketika menjawab pertanyaan keenam ini belum mampu untuk berpikir kritis mengenai fungsi dari komponen penyusun sel surya. 


\section{Kesimpulan}

Berdasarkan data yang diperoleh serta hasil dan pembahasan, maka dapat diperoleh kesimpulan bahwa terdapat 4 pertanyaan yang mana responden sudah mampu untuk berpikir kritis. Kemudian terdapat 2 pertanyaan yang mana responden belum mampu untuk dikatakan dapat berpikir kritis. Diperkirakan responden yang dikatakan belum mampu untuk berpikir tersebut karena kurang teliti dan kurang memahami bacaan yang tersedia. Sehingga ketika menjawab pertanyaan kuesioner, responden belum dapat menjawab dengan benar. Diharapkan untuk kedepannya responden dapat teliti dan memahami terlebih dahulu terhadap bacaan sebelum mengisi jawaban.

\section{Referensi}

Cahyono, Y., \& et al. 2018. Pilot Project Pemanfaatan Sel Surya sebagai Pembangkit Listrik Alternatif untuk Rumah Tangga Di Pulau Gili lyang Sumenep. Jurnal Pengabdian Kepada Masyarakat. 2(1).

Hindun, I., \& et al. 2019. Pemanfaatan Teknologi Tepat Guna Berbasis Solar Cell untuk Mengatasi Permasalahan IRT Nelayan Sapeken Kabupaten Sumenep. International Journal Of Community Service Learning. 3(4).

Malau, Nya Daniaty. 2019. Modul Fisika Lingkungan. Jakarta: FKIP UKI.

Pae, Mycahel Gatsier. 2015. Pemanfaatan Energi Matahari Menggunakan Teknologi Solar Cell Untuk Charger Di Lingkungan Kampus Ist Akprind Yogyakarta. Jurnal Elektrik. 2(1).

Soeparman, Sudjito. 2015. TEKNOLOGI TENAGA SURYA. Malang: UB press. 